\title{
Bożena Frankowska-Kozak, Logonimy podmiotów gospodarczych w pótnocno-zachodniej Polsce w ostatnim dziesięcioleciu XX wieku, Print Group, Szczecin 2009, ss. 293
}

Niewątpliwą zaletą studium Bożeny Frankowskiej-Kozak - co chciałabym zasygnalizować na wstępie - jest samo podjęcie niezwykle trudnego tematu. Nazwy o charakterze „komercyjnym”, funkcjonujące w specyficznej sytuacji komunikacyjnej, do których należy zaliczyć logonimy firm, są dziś przedmiotem naukowej dyskusji specjalistów różnych dziedzin, m.in. socjologów, onomastów, też specjalistów od marketingu i zarządzania.

Recenzowana rozprawa składa się z dwóch rozdziałów o charakterze preliminaryjnym i teoretyczno-metodologicznym: I. Przedmiot badań i założenia metodologiczne (s. 9-52), II. Sposoby nominacji (s. 53-88) oraz dwóch rozdziałów zasadniczych (analitycznych): III. Logonimy derywowane (s. 89-188), IV. Zapożyczenia i stylizacje na język obcy (s. 189-212) i Zakończenia (s. 213-224). Książkę zamykają niezbędne w pracy naukowej: wykazy, indeksy, spisy tabel, bibliografia i streszczenia.

Rozdział I przynosi przegląd literatury przedmiotu - polskiej i obcej (słowackiej, czeskiej i rosyjskiej). Nie jest to omówienie krytyczne stanu badań, ponieważ autorka koncentruje uwagę wyłącznie na formułowanych przez badaczy definicjach chrematonimów - zestawia je, nie wdając się w naukową dyskusję i nie zaznaczając własnego stanowiska w kwestiach spornych. Ta „słowiańska konfrontacja” ujawnia tylko chaos terminologiczny, wielość i synonimiczność terminów, zachodzenie na siebie ich zakresów. Autorka nie podejmuje próby porządkowania tej materii (nie liczy się z pożytkiem, jaki taka próba mogłaby przynieść). Na użytek własny przyjmuje stanowisko Ewy Jakus-Borkowej ${ }^{1}$ w kwestii zakresu chrematonimii (sensu largo): na-

\footnotetext{
${ }^{1}$ E. Jakus-Borkowa, Nazewnictwo polskie, Opole 1987, s. 138.
} 
zwy własne wytworów ludzkich, które nie są trwale związane z krajobrazem (przedmiotów i wyrobów, zjawisk i wydarzeń społecznych, instytucji społecznych). Sięga też po termin „logonim” (por. logo 'artystycznie ukształtowany, przedstawiony symbol albo znak jakiejś rzeczy czy instytucji') w rozumieniu słowackiej badaczki Marii Imrichovej² Za logonimy uznaje „nazwy własne firm, jednostek handlowych, spółek produkcyjno-handlowych, zakładów przemysłowych, lokali użyteczności publicznej” (s. 23). Termin ten przyjął się przede wszystkim w onomastyce słowackiej. Użycie go - zamiast dobrze zadomowionego w onomastyce polskiej terminu „nazwy firm”, wobec konieczności rozróżniania „nazwy oficjalnej” (pełnej, wielowyrazowej nazwy firmy) od „nazwy właściwej” (symbolu firmy) - należy uznać za uzasadnione.

W tej części pracy autorka formułuje też założenia metodologiczne i cele badawcze.

Postępowanie badawcze zasadzać się ma w głównej mierze na typologii logonimów. Na podstawie różnorodnych kryteriów (genetycznych i formalnych) wyłonione zostają: leksemy (polskie i obce), skróty (wyrazów polskich i obcych), skrótowce, złożenia (właściwe i dezintegralne), zestawienia, zdania, zrosty i inne konstrukcje. Autorka deklaruje postępowanie analityczne „według kryterium strukturalnego i semantycznego". Analizę jakościową wspierać ma ,przybliżona" analiza frekwencyjna ${ }^{3}$, służąca wskazaniu nazw: bardzo częstych, częstych, rzadkich i sporadycznych (s. 29).

„Celem pracy jest analiza logonimów podmiotów gospodarczych, które powstały w latach 1990-2000" (s. 24), bliżej - choć niezbyt czytelnie - cel badań zostaje przedstawiony dalej: „Celem pracy jest charakterystyka sposobów nominalizacji logonimów oraz pokazania tendencji, które ujawniły się w procesie tworzenia logonimów w ostatnim dziesięcioleciu XX wieku, poprzez określenie ich aspektów semantycznych i strukturalnych" (s. 30).

Wskazane zostają też wielkość analizowanego zbioru nazw: „Analizie poddano łącznie 4000 nazw podmiotów gospodarczych" (s. 25) oraz źródła: rejestry Wojewódzkiego Urzędu Statystycznego, wybrane czasopisma wydawane na teranie byłych województw: szczecińskiego, koszalińskiego, gorzowskiego i zielonogórskiego, Branżowy katalog firm oraz Panorama firm. Materiał autorka pozyskiwała także za pomocą metod bezpośrednich: wywiadów i ankiet, co należy uznać za słuszne, bowiem motywację semantyczną nazwy rozumianą jako ,impuls pozajęzykowy nazwy"4 można usta-

${ }^{2}$ M. Imrichová, Vymedzénie logonym v slovencine, Prešov 2000, s. 10-11.

${ }^{3}$ Zob. W. Doroszewski, H. Koneczna, W. Pomianowska, Gwary Warmii i Mazur, w: Konferencja Pomorska 1954, Warszawa 1956, s. 129.

${ }^{4}$ A. Cieślikowa, O motywacji w onomastyce, „Polonica” 16, 1994, s. 193-198. 
lić, zapoznając się z konkretną rzeczywistością pozajęzykową i docierając do nazwotwórcy.

Osobny podrozdział poświęcony jest istotnej kwestii, jaką są funkcje logonimów (s. 30-51). Jego celem było zapewne stworzenie przedpola terminologicznego dla problematyki kolejnych (zasadniczych) rozdziałów (II i III). W wydzielonych segmentach tej części pracy (niezbyt fortunnie zatytułowanych: Funkcje logonimów w literaturze lingwistycznej i Funkcje logonimów $w$ materiale badawczym) autorka omawia stan badań we wskazanym zakresie, formułując - niejako przy okazji - własne ustalenia teoretyczne. Przyjmuje słusznie - rozumienie „funkcyjności” logonimów w sensie pragmatycznym jako „wybór i działanie”, a także ,jako rolę, którą pełnią w oficjalnej i nieoficjalnej komunikacji” (s. 37).

Prezentacja funkcji badanych logonimów: komunikatywnej, ekspresywnej (emotywnej), impresywnej (konatywnej), reklamowej przebiega jednak wyraźnie przypadkowo. Czytelnik nie otrzymuje od autorki sygnałów przyjęcia modelu porządkującego analizę. Mankamentem metodologicznym jest brak wyraźnego wskazania płaszczyzny odniesienia wskazanych funkcji logonimów (do składników modelu komunikacji językowej? do składników modelu aktu nominacyjnego?). Zastrzeżenia budzi materiałowe zobrazowanie poszczególnych funkcji - przykładowo, funkcji ekspresywnej nie dostrzegam w nazwach: Trykot, Żakiet, Kwadrat (s. 44-45). Autorka nie dopowiada też, jak rozumie „specyficzne funkcje logonimów”. Specyfiki tej upatrywałabym w odpowiednim zhierarchizowaniu funkcji ujętych we wspomnianym modelu. Nie może zadowalać konkluzja autorki: „Kryterium rozstrzygającym, która funkcja dominuje, jest na ogół opinia odbiorcy komunikatu językowego, jakim ponad wszelką wątpliwość jest logonim" (s. 51).

W kolejnym rozdziale autorka wskazuje dwa sposoby nominacji podmiotów gospodarczych - onimizację i transonimizację. Wydziela 796 logonimów powstałych w rezultacie onimizacji (nazwy motywowane apelatywami z 16 pól semantycznych) i 720 logonimów utworzonych w rezultacie transonimizacji (antroponim / etnonim / toponim $\rightarrow \log$ onim). Ostatnia $\mathrm{z}$ technik nominacyjnych - derywacja - zostaje zaprezentowana osobno, w sposób bardzo drobiazgowy, w III rozdziale zatytułowanym Logonimy derywowane. Autorka dzieli je na jedno- i wieloskładnikowe (grupa I objęła logonimy sufiksalne, dezintegralne i dezintegralno-sufiksalne oraz composita logonimiczne i nominaty abrewiacyjne; w grupie II wyróżniono: zestawienia dwui trójskładnikowe, zestawienia prepozycyjne i logonimy równe wyrażeniom przyimkowym).

Najtrudniejszy w odbiorze, ze względu na nadmierne zagęszczenie pojęciowo-klasyfikacyjne, jest rozdział poświęcony logonimom derywowanym, 
w którym autorka przedstawia drobiazgową analizę formalną materiału i pokazuje słowotwórczą specyfikę nazewnictwa firm.

Mało przejrzysty (nie zawsze konsekwentnie stosowany) jest system skrótów przyjętych w rozdziale poświęconym zestawieniom (np. A - przymiotnik, Adj-przymiotnik), częste są niekonsekwencje w zapisie struktury modelowej. Trudno niekiedy zgodzić się z rozstrzygnięciami autorki dotyczącymi wskazywanych modeli i ich realizacji leksykalnych, por. model trójskładnikowy $\mathrm{S}+\mathrm{An}+\mathrm{An}$ i jego realizację [GOLD - ZDZISŁAW MOLENDA], w której pojawia się zestawienie antroponimiczne (imię i nazwisko), a nie dwa niezależne antroponimy - konieczny byłby zatem dodatkowy symbol w i tak już nadmiernie skomplikowanym układzie: przy wykorzystaniu zaproponowanych przez autorkę skrótów poprawny byłby zapis $\mathrm{S}+(\mathrm{An}+\mathrm{An})$.

Nie dostrzegam sensu uwzględniania danych procentowych dotyczących rekcji przyimków (s. 175) w strukturach logonimów z wyrażeniami przyimkowymi (o funkcji prymarnie lokalizującej), oczywiste bowiem jest, że o postaci morfologicznej grupy imiennej w stosunku lokatywnym decyduje semantyka predykatu przyimkowego (tu: miejsce - lokalizacja statyczna). Uwagi typu: „przyimek na w 100\% wiąże się z miejscownikiem [NA ROGU]” (s. 175) itp. rażą swoją oczywistością.

Rozdział IV, zatytułowany Zapożyczenia i stylizacje na język obcy, pokazuje przede wszystkim udział elementów obcych w strukturze logonimów. Za niefortunne uznać należy użycie przez autorkę quasi-terminu „logonim-zapożyczenie" (s. 190), wobec faktu, że prezentowany materiał to logonimy powstałe przez onimizację apelatywów zapożyczonych do polszczyzny z języków obcych, nie zaś logonimy zapożyczone z obcych systemów onimicznych. Sprzeciwiłabym się też mechanicznemu potraktowaniu obcych ekwiwalentów i wariantów (graficznych, fonetycznych) nazw polskich, np. imion motywujących logonimy, jako „translacji / tłumaczenia”. O tłumaczeniach logonimów nie można mówić w odniesieniu do wskazanych w pracy przykładów typu: Christine Jewellery, Margo's Gifts Shop. Są to nazwy tworzone przez ich kreatorów bezpośrednio w języku angielskim (świadczyć mają przecież o kompetencji, wykształceniu, „europejskości” ich twórców). Odpowiadające im polskie nazwy - Sklep Jubilerski Krystyny, podobnie jak Małgorzaty sklep $z$ upominkami - nigdy nie zaistniały w akcie nominacji (jako jej ,produkt finalny”). W szczególnym dyskursie między kreatorem nazwy a odbiorcą (odbiorcami) sięgnięcie po obce warianty (graficzne, fonetyczne) nazw polskich, tak samo jak użycie logonimów fundowanych przez obce apelatywy, jest stylizacją językową, choć dokonywaną na różnych poziomach języka i za pomocą różnych środków. Jest też rodzajem gry, jaka toczy się w układzie: kreator nazwy - nazwa - odbiorcy. 
Każdy z rozdziałów analitycznych autorka zamyka podsumowaniem, w którym formułuje wnioski o udziale procentowym wyodrębnionych grup logonimów w całości materiału. Stosunki procentowe pokazują wykresy i diagramy (np. Wykres 1. Procentowy stosunek występowania logonimów powstatych $w$ wyniku onimizacji i transonimizacji, s. 84, Wykres 3. Stosunek wystepowania poszczególnych typów skrótowców, s. 118).

W Zakończeniu autorka przytacza dane liczbowe i procentowe dotyczące udziału wskazanych technik: onimizacji, apelatywizacji, derywacji w tworzeniu logonimów (analiza dowodzi, że techniką najczęściej wykorzystywaną jest derywacja). W tej części pracy formułuje też liczne wnioski szczegółowe, wynikające z wszystkich cząstkowych analiz przeprowadzonych w rozprawie. Wadą kompozycyjną tej części pracy są powtarzające się wielokrotnie te same konkluzje i uogólnienia. Jako podsumowanie całości traktuje autorka odniesienie logonimów powstałych w ostatnim dziesięcioleciu XX wieku do „warunków dobrej nazwy”, ustalonych w 1936 roku przez Zenona Klemensiewicza. Dane, jakie uzyskała na podstawie ankiet, pozwalają wesprzeć dość ogólnikowe wnioski dotyczące spełniania przez logonimy owych warunków. Brak rzetelnej analizy wyników badań przeprowadzonych za pomocą metod bezpośrednich, mimo deklarowanej przez autorkę orientacji pragmatycznej, należy uznać za oczywiste zaniechanie. Wobec braku charakterystyki respondentów końcowy komentarz socjolingwistyczny - „Badana grupa respondentów tworzy warstwę społeczną, posługującą się różnymi odmianami polszczyzny, np. socjolektami czy profesjolektami” (s. 223) - jawi się w zakończeniu pracy jako niczym nieuzasadniona amplifikacja.

Uznanie budzi bogata literatura przedmiotu (259 pozycji, w tym liczne prace obcych autorów). Szkoda, że nie służy ona autorce do rozwinięcia naukowej dyskusji, ani też do trafnego skomentowania wyników, do których dochodzi w rozprawie.

Wychodząc z przyjętych założeń teoretyczno-metodologicznych, autorka osiagnęła cele badawcze w wyznaczonym zakresie. Pokazała, że struktura gramatyczno-leksykalna logonimów firm tworzy wiele modeli. Przeprowadzona na obszernym materiale semantyczna i strukturalna analiza stała się podstawą do wskazania najczęstszych technik i modeli nominacyjnych, pozwoliła też zauważyć wyraźne tendencje: do przeszczepiania na grunt polski wzorców zachodnich (zarówno motywacyjnych, jak i ściśle językowych) oraz do tworzenia struktur hybrydalnych i okazjonalizmów. Wskazanie struktur (modeli) logonimów nie wzbogaciło jednak naszej dotychczasowej wiedzy o funkcjonowaniu tych nazw - co więcej, raczej zaciemniło obraz ich roli komunikacyjnej. Zbyt mało jest w opracowaniu refleksji na temat kulturowej (cywilizacyjnej) genezy wybranej kategorii nazw własnych. 
Zmagając się z niezwykle trudną materią, jaką są chrematonimy (logonimy), autorka nie znalazła do nich właściwego klucza. W tym przypadku potrzebne było podejście eklektyczne, bazujące na dokonaniach nie tylko językoznawstwa tradycyjnego (onomastyki tradycyjnej), ale też socjo- i pragmaonomastyki oraz onomastyki kulturowej. Propozycje klasyfikacji (semantycznej i formalnej) logonimów to sugestie metodologiczne i merytoryczne, które nie mogą oddać obrazu złożoności i skali zjawiska, jakim są logonimy.

Irena Sarnowska-Giefing 